\title{
Рахимбекова Б.
}

кандидат исторических наук, научный сотрудник проекта

МОН РК «Образовательная миграция из Казахстана: тенденции, факторы и

социально-политические последствия», Казахский национальный университет имени аль-Фараби, Казахстан, г. Алматы, e-mail: rahimbekovabakyt@gmail.com

\section{СОВРЕМЕННЫЕ ТЕНАЕНЦИИ \\ ОБРАЗОВАТЕАЬНОЙ МИГРАЦИИ В РОССИЙСКОЙ ФЕАЕРАЦИИ}

В статье рассматриваются основные тенденции и особенности развития образовательной (учебной) миграции в России в эпоху глобализации и интернационализации образовательного пространства. Современное рассмотрение проблем образовательной миграции является актуальным, поскольку социальные, экономические и политические изменения на постсоветском пространстве отразились на отношении, мотивированности и готовности к образовательной миграции со стороны различных групп социума, и прежде всего, молодого поколения. Автор рассматривает факторы, влияющие на масштабы, структурные характеристики и направления потоков внешней и внутренней учебной миграции в России. Анализируются эффекты образовательной миграции и возможности управления ею в целях недопущения "утечки мозгов». Регулирование данной сферы является очень сложным, но государственно важным направлением, определяющим потенциал развития ^юбого государства, способным обеспечить качество и количество человеческого капитала. Аанная статья подготовлена в рамках проекта МОН РК «Образовательная миграция из Казахстана: тенденции, факторы и социально-политические последствия». ОАной из приоритетных целей данного проекта является исследование опыта зарубежных стран, в частности Российской Федерации, в сфере мониторинга и регулирования студенческой миграции, определения механизмов Аля стимулирования возвращения молодежи после получения образования за рубежом.

Ключевые слова: международная образовательная миграция, высшее образование, Российская Федерация, интернационализация образования, академическая мобильность.

\author{
Rakhimbekova B. \\ Candidate of Historical Sciences, Researcher at the \\ MES RK project «Educational Migration from Kazakhstan: Trends, Factors, \\ and Socio-Political Consequences», al-Farabi Kazakh National University, \\ Kazakhstan, Almaty, e-mail: rahimbekovabakyt@gmail.com \\ Modern trends in educational migration in Russian Federation
}

The article discusses the main trends and features of the development of educational (training) migration in Russia in the era of globalization and the internationalization of the educational space. Modern consideration of the problems of educational migration is relevant, thus social, economic and political changes in the post-Soviet space affected attitudes, motivation and readiness for educational migration from various groups of society, and above all, the younger generation. The author considers the factors influencing the scale, structural characteristics and directions of the flows of external and internal educational migration in Russia. The effects of educational migration and the possibilities of managing it in order to prevent «brain drain» are analyzed. Regulation of this area is very difficult, and an important state objectives, determining the development potential of any state, capable of ensuring the quality and quantity of human capital. This article was prepared within the framework of the MES RK project «Educational migration from Kazakhstan: trends, factors and socio-political consequences»; One 
of the priority objectives of this project is to study the experience of foreign countries, in particular the Russian Federation, in the field of monitoring and regulating student migration, identifying mechanisms to stimulate the return of young people after receiving education abroad.

Key words: international educational migration, higher education, Russia, internationalization of education, academic mobility.

Рахимбекова Б.

тарих ғылымдарының кандидаты, ҚР БжҒМ-нің «Қазақстаннан бағытталған білім алу миграциясы: үрдістері, алғышарттары мен әлеуметтік-саяси салдары» жобасының ғылыми қызметкері, әл-Фараби атындағы Қазақ ұлттық университеті, Қазақстан, Алматы қ., е-mail: rahimbekovabakyt@gmail.com

\title{
Ресей Федерациясында білім алу миграциясының қазіргі тенденциямары
}

\begin{abstract}
Мақалада жаһандану дәуірінде және оқу кеңістігін интернационалдандыру Ресейдегі білім беру (оқыту) миграциясының негізгі үрдістері мен ерекшеліктері талқыланды. Посткеңестік елдердегі әлеуметтік, экономикалық және саяси өзгерістер қоғамның әртүрлі топтарынан, ең алдымен, жас ұрпақтан шыққан білім беру миграциясына көзқарастарды, мотивацияны және Аайындықты ескере отырып, білім алу миграциясының мәселелерін қазіргі кездегі өзекті мәселе болып табылады. Автор Ресейде сыртқы және ішкі білім алу миграциясының ауқымын, құрылымдық сипаттамаларын және бағыттарын қозғайтын факторларды қарастыралы. Білім миграциясы мен «ақылдылардың шет елге жылыстап кетуі» мәселесін болдырмау үшін оны басқару мүмкіндіктері талданады. Бұл саланы реттеу өте қиын, бірақ адами капиталдың сапасы мен санын қамтамасыз етуге қабілетті кез келген мемлекеттің даму әлеуетін анықтайтын маңызды мемлекеттік бағыт. Бұл мақала ҚР БҒМ «Қазақстаннан бағытталған білім алу миграциясы: үрдістер, факторлар және әлеуметтік-саяси салдар» жобасының шеңберінде дайындалды; Бұл жобаның басым міндеттерінің бірі шетелдіктердің, соның ішінде Ресей Федерациясы студенттерінің миграциясын бақылау және реттеу саласындағы тәжірибесін зерттеу, шетелде білім алғаннан кейін жастарды қайтаруды ынталандыру тетіктерін анықтау болып табылады.

Түйін сөздер: халықаралық білім беру миграциясы, жоғары білім, Ресей Федерациясы, білім беруді интернационализациялау, академиялық ұтқырлық.
\end{abstract}

\section{Введение}

Современные высокоинтеллектуальные технологии и научные, профессиональные знания являются ведущими драйверами мировой и национальных экономик; инвестиции в человеческий капитал стали выгодной сферой приложения финансов, поэтому во многих странах мира происходит интенсивное развитие науки и системы образования. Сегодня никто не оспаривает тот факт, что образование - это социальное благо и неотчуждаемый капитал, значительно повышающий шансы индивидуума улучшить уровень качества жизни.

Существующие тренды глобального мира ярко свидетельствуют о расширении международного сотрудничества в сфере образования и создании образовательного пространства с многомиллиардной инфраструктурой. По данным Организации экономического сотрудничества и развития, число иностранных студентов в мире достигло 5 млн. чел. Только за период с 1999 г. по 2016 г. количество студентов, обучающихся в вузах других стран, увеличилось c 2 млн. до 5 млн.чел. и эта тенденция будет возрастать, по прогнозу ОЭСР (Организации экономического сотрудничества и развития), в соответствии с социально-экономическими, демографическими изменениями, количество студентов, выбирающих для получения образования зарубежные вузы, достигнет 8 млн. к 2025 г. (Education at Glance, 2018: 218). Это, безусловно, актуализирует необходимость проведения исследований факторов, трендов, последствий образовательной миграции как для стран-экспортеров образовательных услуг, так и стран, из которых наблюдаются высокие темпы студенческой мобильности.

Данная статья подготовлена в рамках проекта МОН РК «Образовательная миграция из Казахстана: тенденции, факторы и социальнополитические последствия». Одной из целей реализуемого проекта является изучение опыта зарубежных стран в сфере регулирования образовательной миграции, выявление механизмов для стимулирования возвращения молодежи после получения образования за рубежом. В этой связи возникает целый ряд исследовательских 
вопросов, актуальных для всех стран, откуда наблюдается отток талантливой молодежи: насколько реальны ожидания возвращения молодых специалистов из-за рубежа после окончания учебы? Какие финансовые и профессиональные стимулы необходимы, чтобы повернуть процесс «утечки молодых умов» вспять.

В этом отношении исследовательский интерес вызывает изучение ситуации с образовательной (учебной) миграцией в Российской Федерации. Интеграционные и глобальные процессы в мировом сообществе оказали значительное влияние на динамику образовательной миграции в Российской Федерации, где наблюдается проявление двух тенденций: с одной стороны, российские вузы ежегодно принимают десятки тысяч студентов из стран ближнего и дальнего зарубежья, с другой стороны, увеличивается количество молодых россиян, желающих получить образование в ведущих вузах Европы, США и ряда азиатских стран. Российскими учеными и специалистами проводятся интересные исследования по образовательной миграции в рамках научных проектов: проект Фонда «Наследие Евразии» «Учебная иммиграция из Новых независимых государств (ННГ) в Россию: состояние, потенциал и перспективы», «Российские студенты за рубежом: перспективы возвращения в Россию» (20012002г.г.), международные проекты «Атлас» (Project Atlas); проект Ассоциации университетов «Отображение мобильности преподавателей и студентов университетов». Разработки экспертов Центра социологических исследований Федерального агентства по образованию Российской Федерации, Отдела науки и инноваций Института мировой экономики и международных отношений РАН направлены на изучение структуры академической мобильности в зарубежные вузы студентов, преподавателей и научных сотрудников.

Изучение опыта РФ, безусловно, является важным в силу того, что в российских вузах по состоянию на 2018 г. обучается свыше 70000 молодых казахстанцев (Каждый пятый казахстанский студент учится за границей // Today. $\mathrm{kz}$ - круглосуточный информационный портал. 2017). Задача состоит в том, чтобы на основе сравнительного анализа выявить социально-политические последствия, индикаторы оценки образовательной миграции, ее эффективности и негативных последствий как для России, так и Казахстана, в целом определить риски, вызванные внешней образовательной миграцией.

\section{Методология исследования}

В первую очередь необходимо определить содержание основных дефиниций «образовательная миграция», «учебная миграция», «международная образовательная миграция», «международная студенческая миграция», «академическая мобильность». На наш взгляд, «международная образовательная миграция» представляет собой более широкое понятие и объединяет перемещения людей между странами с целью получения образования и повышения квалификации различного уровня и на различные сроки (в том числе миграцию школьников, студентов, аспирантов, докторантов, стажеров, повышающих квалификацию профессионалов). «Международная учебная миграция» представляет собой более узкое понятие, которое является составной частью международной образовательной миграции и представляет собой перемещения между странами мигрантов, которые обучаются в школах, колледжах и университетах.

В данной статье будет использоваться широкий подход к вопросу образовательной миграции, который включает в себя, в том числе, миграцию высококвалифицированных специалистов и краткосрочную студенческую миграцию (языковые курсы, обучение без получения диплома) на примере Российской Федерации.

Изучение социально-демографических процессов, связанных с феноменом миграции, имеет достаточно длительную исследовательскую традицию и относится ко во второй половине XIX века, периоду так называемого «миграционного бума», как следствия процессов урбанизации и индустриализации. Казахстанский исследователь, социолог А. Забирова проанализировала основные теории и концепции в зарубежной социальной науке (Забирова, 2003:131). Вся совокупность теоретико-концептуальных подходов подразделяется на теории и концепции двух уровней: макро- и микроуровни. Макротеоретический подход рассматривает феномен миграции, в том числе и образовательной, через призму социально-экономических, политических парадигм (теория неоклассической экономики, теория общественного капитала, теория кумулятивной причинности и т.д.). Тогда как микротеоретический подход выражается в оперировании такими понятиями как: рациональный выбор, прагматизм мышления, стратегия успеха личности и др., связанные с социально-психологическими измерениями самого субъекта миграции, 
отдельно взятого индивидуума. Такой подход характерен для ряда работ западных исследователей студенческой миграции, к примеру, Nishimuta Y. (Nishimuta, 2008: 133-150), Goździak E. (Goździak, 2014: 392-414), Lulle A., Buzinska L. (Lulle, Buzinska 2017:1362-1378.), Beech S. (Beech, 2017: 285-303). Их изучение показывает, что они больше затрагивают вопросы идентичности и самоидентификации, культурной адаптации и ассимиляции, чем факторы и последствия этого процесса. Фокус внимания исследователей смещается на индивидуальный уровень, нежели на связь феномена образовательной миграции с дефинициями «государство», «нации», «общество», «экономика страны». К примеру, британский публицист Д. Гудхарт описывает современный мир как конфликт людей «любого места» (anywheres) и людей «этого места» (somewheres). Люди первой категории хорошо образованы и успешны, они ценят автономию и мобильность, они не привязаны к конкретному месту и уверены в том, что они найдут себе применение где угодно (Goodhart, 2017).

Еще одно методологическое направление связано с теориями постиндустриального общества и глобализации Д. Белла, П. Дракера, и др., позволяющими раскрыть масштабы и темпы современной образовательной миграции, через призму глобализации, когда мировое пространство преобразуется в единую зону, где свободно перемещаются информация, капиталы, товары и услуги, распространяются идеи, знания и передвигаются их носители в условиях относительной прозрачности границ как политических, так и культурных (Salt, 1997). За последние десятилетия на уровне мировой системы в отношениях между национальным государством и транснациональным капиталом произошли значительные изменения, для понимания которых следует учитывать исторический контекст. Усиливающаяся интернационализация образования сопровождается активизацией студенческой миграции, относящейся к числу наиболее динамично растущих потоков межстрановых людских передвижений. Прием иностранных студентов оказывает существенное позитивное воздействие на страны их обучения, обеспечивая эти страны высококвалифицированными кадрами и повышая их доходы за счет экспорта образовательных услуг. Поэтому на рынке образовательных услуг между развитыми странами развернулась настоящая конкуренция за привлечение иностранных студентов. Многие страны происхождения студентов также оказываются в выигрыше от обу- чения своих граждан за границей, однако немалая их часть все же в той или иной мере страдает от «утечки умов». Политика целого ряда таких стран не ограничивается содействием обучению своих граждан за рубежом. В ней все четче прослеживается направленность на создание условий для возвращения таких мигрантов на родину и использование позитивного потенциала взаимодействия с соотечественниками, оставшимися после завершения обучения за рубежом.

Научный интерес представляет использование для анализа образовательной миграции подхода «Push-Pull-Mooring». (Simon Nimako, 2013) Эта теоретическая схема позволяет рассматривать влияние различных факторов на объем потока студенческой мобильности. Согласно этому подходу, факторы, влияющие на образовательную миграцию, разделяются на «выталкивающие», то есть те, которые вынуждают студента отправиться учиться в другую страну, «притягивающие», то есть положительные характеристики «принимающего» места (страны/ города), и «удерживающие», представляющие собой положительные характеристики «отправляющего» места (страны/города).

Еще один теоретический дискурс в анализе последствий международной образовательной миграции связан с политической составляющей, а именно с понятием «мягкая сила» («soft power»), когда наука и образование рассматриваются как инструмент реализации внешнеполитических интересов государств, прежде всего ведущих мировых лидеров (Масич, 2015:118).

Таким образом, отметим, что на сегодняшний день имеется целый ряд теоретико-методологических подходов и концепций, позволяющих исследовать природу, факторы, направлениия и последствия образовательной (учебной) миграции как в глобальном масштабе, так и ее региональные паттерны.

\section{Обзор литературы}

Начало исследованию проблем образовательной миграции положили ученые из США и Великобритании, где уже в середине прошлого века наблюдалось значительное число иностранных студентов. Отметим, что до начала 2000-х гг. студенческая миграция практически не выступала в роли отдельного предмета исследования в работах по международной миграции. Вопросы образовательной миграции затрагивались в научных исследованиях и аналитических докладах, однако, как правило, были частью работ 
по анализу миграционной ситуации какой-либо страны, региона и т.д. В связи с активизацией образовательной миграции в последние десятилетия расширился и спектр исследований по данной тематике. В основном, студенты-иностранцы изучались как часть принимающего их социума с позиций психологии и социологии (Самофалова 2015: 105).

Первые научные работы, посвященные непосредственно образовательной миграции, были опубликованы в начале 2000-х гг. Осознание важности важности международной учебной миграции подтверждается включением данной проблематики в ежегодные доклады ОЭСР и МОМ. В 2001 г. в состав ежегодной публикации ОЭСР «Trends in International Migration» вошел самостоятельный раздел по международной студенческой миграции, а в ежегодном отчете World Migration Международной организации по миграции в 2008 г. появилась глава о студенческой мобильности и интернационализации высшего образования. Целый ряд публикаций в таких журналах как «Journal of Development Economics», «Journal of Human Resources», «Journal of Labour Economics», «Higher Education Management», «Journal of Higher Education», «International Journal of Educational Development» посвящены различным аспектам проблематики образовательной миграции.

Масштабы, структура потоков, движущие факторы учебной миграции и академической мобильности рассматриваются в настоящее время в работах ученых из большинства европейских стран, США, Канады, Японии, Китая (Rajika Bhandari, C. Didelon, Y. Richard; E. Neumayer, R. Perkins, T. Wotherspoon и др.) (Самофалова 2015: 105). Значительное место занимают статистические обзоры и анализ нормативно-правовой базы международной студенческой миграции, особенностей политики в данной сфере (Ç. Özden, M.W. Schiff; K. Gürüz; C. Gribble; E. Colucci, H. Davies, J. Korhonen, M. Gaebel; J. Zongand) (Самофалова, 2015:107). Интенсифицировались исследования со стороны учёных, представляющих динамично развивающиеся азиатские страны (Tan J. (Tan, 2013:1-5), Yue C. (Yue, 2013: 18-28.), Choudaha R. (Choudaha, 2017:825-832).

Проблемы «утечки умов», качества человеческого капитала, экономические, социальные и политические последствия студенческой миграции через призму междисциплинарных исследований в области социально-экономической географии (Collins F. (Collins, 2012:296-304), те- ории и практики развития и постколониальных исследований (Madge C., Raghuram P., Noxolo, P. Madge, C., (Raghuram, Noxolo 2009: 34-45), менеджмента образования. Среди популярных на Западе является исследование проблемы «утечки умов» и «обмена умами» (Dustmann C., Fadlon I., Weiss Y. (Dustmann, Fadlon, Weiss, 2011:58-67). Однако, тема «возвратной миграции», т.е. возвращения студентов на родину после получения престижного зарубежного образования лишь недавно стала предметом изучения (Bijwaard G.E., Wang Q. (Bijwaard, Wang, 2016: 31-54), Wu C., Wilkes R. (Wu, Wilkes, 2017:123-132).

На постсоветском пространстве наиболее полно образовательная миграция изучена в Российской Федерации (Е.Н. Алексеева, А.Л. Арефьев, К.А. Гаврилова, И.Г. Дежина, Н.М. Дмитриев, Л.И. Леденева, Е.В. Письменная, С.В. Рязанцев, Е.В. Шевцова, Ф.Э. Шереги, Е.Б Яценко и др.). Так, например, А.Л. Арефьев рассматривает вопросы конкурентоспособности России на рынке экспорта образовательных услуг, С.В. Рязанцев и Е.Е. Письменная рассматривают различные аспекты образовательной миграции - масштабы, тенденции и последствия эмиграции ученых и высококвалифицированных специалистов из Российской Федерации за рубеж, проблемы учета эмиграции в России, социальные эффекты учебной иммиграции в Российскую Федерацию (Письменная, Рязанцев, Скоробогатова 2015:156-163). Леденева Л.И. делает акцент на исследовании последствий образовательной миграции - проблеме «утечки умов», Дмитриева Н.М. и Цапенко И.П. анализируют статистические социально-демографические показатели, основную географию международных образовательных стажировок и различные барьеры, с которыми сталкиваются студенты, приезжающие на учебу в другую страну, Бекетов Н.М. исследует рынок образовательных услуг и подробно расписывает выгоды международной академической мобильности как принимающих стран, так и стран-реципиентов. Такие исследователи как Константиновский Д.Л., Вознесенская Е.Д. и Чередниченко Г.А. в своей работе «Интернационализация образования и российская молодежь: открытия, обретения, результативность» (Константиновский, Вознесенская, Чередниченко 2014) исследуют образовательную миграцию качественными методами, с помощью глубинного интервью, но с точки зрения воспроизводства и влияния определенных социокультурных институциональных образцов поведения, привычек и навыков, приобретенных в 
ходе обучения за границей, на карьерные траектории и мировоззрение уже после возвращения на родину российских специалистов. Исследователи больше внимания уделяют российской государственной политике и анализу опыта других государств. Здесь наблюдается очевидный крен в сторону исследований в рамках государственнической парадигмы (Выхованец О. (Выхованец URL:// http://www.fms.gov.ru /about/ science /science_session.), Громова Е., Бояркин Г. (Громова, Бояркин, 2011:105-113), Волох В., Гришаева С. (Волох Гришаева 2017:80-87). Образовательная миграция также исследуется в контексте теорий «социально-экономической глобализации» (Новиков В. (Новиков 2011:17-30), «мягкой силы» России (Фоминых А. (Фоминых 2014:28-31).

Всю совокупность исследовательской литературы по проблеме можно условно разделить по тематическому содержанию на следующие группы:

1) образование и образовательная миграция в эпоху глобализации;

2) международный рынок образовательных услуг

3) региональные аспекты образовательной миграции (Россия, Китай, европейские страны, США);

4) проблемы социокультурной адаптации иностранных студентов в странах обучения; образовательная миграция и этносоциальные конфликты в вузах;

5) экспорт образовательных услуг как форма экономических инвестиций и пути их совершенствования;

6) влияние образования на демографическую ситуацию;

7) образовательная миграция и «утечка мозгов»;

8) государственная политика в сфере регулирования образовательной (учебной) миграции;

9. правовые механизмы международной образовательной интеграции;

10. интернационализация образования и развитие высокопрофессиональных ресурсов, представляющих интеллектуальный капитал общества;

11. факторы, влияющие на масштабы и направления потоков студенческой миграции;

12. структурные характеристики студенческой миграции;

13. эффекты студенческой миграции и возможности управления ее потоками.

Таким образом, изучение исследований по образовательной миграции показывает, что при всей их значимости выявлена слабая изученность с точки зрения именно ее политических последствий, также недостаточно исследований о мотивах, повседневных поведенческих практик, основных черт характера и динамики изменения мировоззренческих установок, побуждающих молодежь получать образование за рубежом.

\section{Основная часть}

В России не ведется специальная статистика о студентах, выехавших за рубеж. В исследованиях российских ученых, посвященных образовательной миграции, приводятся цифры из докладов ЮНЕСКО. Последние данные относятся к 2016 году. Так, согласно этим сведениям, 50642 студента проходят обучение в зарубежных вузах, в то же время 173672 иностранных студента получают образование в российских вузах.

Среди основных факторов, влияющих на образовательную миграцию как в мире в целом, так и России, в частности, можно выделить следующие:

1) интернационализация учебного процес$\mathrm{ca}$, формирование интегрированного образовательного пространства на основе унификации учебных программ, дескрипторов и стандартов для взаимного признания документов об образовании;

2) коммерциализация образования, т.е. трансформация системы высшего образования из социального института в рынок образовательных услуг;

3) конкуренция за экономические дивиденды и доходы от интеллектуального капитала странами-реципиентами.

Демографический фактор также является одним из определяющих в образовательной миграции для России как «принимающей стороны». Российская Федерация в реализации миграционной политики нацелена на привлечение и удержание в стране востребованных на рынке труда молодых специалистов из числа мигрантов, главным образом, из стран постсоветского пространства, получающих образование в российских вузах. Причиной тому являются складывающаяся демографическая ситуация в современной Россией с явной тенденцией к сокращению народонаселения, и снижение доли трудоспособной ее части (https://www.csr.ru/wpcontent/uploads/2017/11/Report-Demography-web. pdf.). 
Президентом РФ В.В. Путиным была утверждена разработанная Федеральной миграционной службой РФ «Концепция государственной миграционной политики Российской Федерации на период до 2025 года», в соответствии с которой в приоритетные направления была поставлена задача по привлечению иностранных студентов для получения российского образования, для решения которой предполагается введение упрощенного порядка получения студентами вида на жительство в Российской Федерации, предоставление жилья, обеспечение рабочих мест после окончания учебного заведения, финансовая поддержка ВУЗам, обучающим иностранцев и другие (https://www.consultant.ru/document/ cons _doc_LAW_131046/).

Несмотря на указанные негативные тенденции в демографической ситуации, определенный сегмент российской молодежи ориентирован на обучение в зарубежных вузах, с возможным дальнейшим трудоустройством. Проведенные в России исследования выявили, что уезжают за границу в основном для обучения в магистратуре и докторантуре. Это связано с тем, что это более зрелые молодые люди, ясно осознающие свои потребности и перспективы. Второй, немаловажный аспект, финансовый, магистратура обходится дешевле в силу более короткого срока обучения (Трофимов, Трофимова 2017).

В целом, причинами для образовательной миграции молодого поколения россиян, согласно проводимых в России исследований, являются:

1) определение будущей жизненной стратегии и профессиональные перспективы выпускников на рынке труда;

2) высокое качество обучения за рубежом. Возможность академической свободы, отсутствие стандартов и шаблонов, характерных для постсоветского образования;

3) высокий уровень жизни за рубежом;

4) стремление открыть для себя новые страны, культуры;

5) желание быть более самостоятельными и приспособиться к новым жизненным обстоятельствам, новому окружению;

6) погружение в языковую среду;

7) иммиграционная политика принимающих стран.

На решение молодежи уехать обучаться за границу влияет и сформированный СМИ позитивный имидж развитых стран, которые представляются как благополучные для проживания и реализации профессиональных амбиций, осо- бенно на фоне недовольства российской действительностью (социальной сферой, уровнем политических и гражданских свобод, коррупцией, другими негативными проявлениями в обществе и во власти).

Рассматривая страновые предпочтения молодых россиян для получения высшего образования, отметим, что в тройку входят: Германия, Великобритания и США. Образовательные программы высокорейтинговых вузов Чехии, Франции, Канады, Италии и Финляндии также вызывают интерес у российской молодежи.

Какие же особенности образовательных систем указанных стран привлекают молодых россиян? Отличительной чертой германской системы образования является ее практикоориентированность: будущие специалисты $2 / 3$ времени проводят на предприятиях, и только $1 / 3$ времени выделяют для теоретического обучения в вузе, что позволяет координировать соответствие теоретических знаний с реальными условиями труда.

Признанное во всем мире высшее образование в США имеет тесную связь с корпорациями, финансовыми и бизнес-структурами. Создание банка данных выпускников позволяет работодателям приглашать на свободные вакансии талантливых выпускников ведущих вузов страны.

Престижным является британское университетское образование с его механизмами постоянного саморегулирования и самосовершенствования. Связь между образованием и профессиональной практикой осуществляется посредством совместных разработок образовательных программ с потенциальными работодателями.

В целом, студенты, обучающиеся в США, по данным исследований, социологических опросов выглядят более прагматичными: для них главная мотивация для учебы за рубежом - возможность овладеть компетенциями, необходимыми для достижения большей конкурентоспособности на рынке труда. В этом смысле, такие молодые люди рассматривают обучение за рубежом как ступень к дальнейшей профессиональной карьере вне России. Для них также очень важен фактор финансового и материального благополучия.

Как мы отмечали выше, в Российской Федерации имеются серьезные наработки, посвященные проблемам образовательной миграции, начиная уже с 1992 года. В качестве примера одного из наиболее результативных исследований можно назвать проект «Российские студенты за 
рубежом: перспективы возвращения в Россию» (2001-2002 гг.). Не принимая во внимание, необходимость корректировки количественных показателей, можно отметить релевантность многих научных результатов проекта современному состоянию контента и направленности образовательной миграции в России. В статьях к.э.н., старшего научного сотрудника лаборатории анализа и прогнозирования миграции Института народнохозяйственного прогнозирования РАН Леденевой Л.И. (Леденева, 2002:177-196) отмечается, что россияне приобретают в зарубежных вузах разнообразные специальности: физика, математика, компьютерные технологии, химия, биология, экология, экономика, история, социология, политология, право, филология, педагогика. Заслуживает внимания факт, что учиться за границу едет больше гуманитариев и экономистов, чем естественников и технарей. Специалисты объясняют это традиционно высоким уровнем российского образования в области естественных и технических дисциплин.

Важный аспект обучения за рубежом - это финансирование. В целом, зарубежное образование является элитарным, однако, в последние десятилетия появляются возможности и для талантливой мотивированной молодежи из менее обеспеченных семей, благодаря различного рода программам грантового финансирования, предоставляемым ведущими зарубежными вузами, которые активно участвуют в глобальной конкуренции за интеллектуальный капитал.

Исследователи выделяют следующие источники финансирования:

1) стипендии, предоставляемые университетами, с полным или частичным возмещением затрат;

2) гранты различных фондов;

3) собственные средства;

4) exchange programs (программы обмена между университетами).

Таким образом, наблюдающаяся на протяжении последнего десятилетия тенденция развития данного процесса носит стабильный характер. Миграция за рубеж для учебы и профессиональной подготовки, являясь существенной частью международной интеллектуальной миграции, безусловно, заслуживает положительной оценки. Молодые россияне получают доступ к современным технологиям, осваивают иностранные языки, интегрируются в международное научно-профессиональное сообщество. Вернувшись на родину после завершения учебы, именно эти талантливые молодые ученые и специалисты, приобретя дополнительные знания и опыт, могут внести вклад в развитие российской науки и улучшение экономики. Однако, реальность такова, что выезд молодых людей за рубеж на учебу влечет за собой потерю интеллектуального потенциала, «утечку» умов в случае их невозвращения.

В этой связи возникает целый ряд вопросов, актуальных для всех стран, откуда наблюдается отток талантливой молодежи: насколько реальны ожидания возвращения молодых специалистов из-за рубежа после окончания учебы? Каковы финансовые и профессиональные стимулы необходимы, чтобы повернуть процесс «утечки молодых умов» вспять? В 2015 году президент РФ Владимир Путин на заседании совета по науке и образованию призвал обратить внимание на деятельность иностранных фондов, которые «шарят по школам... под видом поддержки талантливой молодежи», «на самом деле, как пылесосом высасывают, и все уже прямо со школы абитуриентов берут, и на гранты сажают и уво3ят» (https://ria.ru/society/20150624/1084949791. $\mathrm{html).} \mathrm{Справедливости} \mathrm{ради} \mathrm{отметим,} \mathrm{что} \mathrm{Рос-}$ сийская Федерация проводит аналогичный подход по выявлению талантливой молодежи из регионов бывшего СССР, делая на них ставку для приращения интеллектуального и социально-демографического капитала современной России.

В среднем, из всех опрошенных намерения жить и работать в России высказывают только один человек из пяти. Остаться за рубежом мечтает примерно каждый десятый. В целом же доминируют гибкие миграционно-возвратные настроения. Это значит, что $60 \%$ респондентов определенно заявили, что вернутся на родину только при определенных условиях, прежде всего - при наличии там возможностей для реализации полученных компетенций. В планировании ближайшей перспективы - сразу по окончании программы - молодые люди более определены и высказывают явное предпочтение западной ориентации: 45\% намерены остаться на Западе работать и еще $19 \%$ - продолжить там образование. Намерение остаться сразу после окончания учебы у $64 \%$ респондентов, и лишь $18 \%$ учебных мигрантов решительно собираются вернуться в Россию. В основном возвращаются из Европы те, кто получал общественно-гуманитарное образование - они без оптимизма оценивают перспективы найти работу за рубежом (Леденева, 2014: 35-42).

Базируясь на материалах российских исследований, было выявлено, что оптимальная 
модель профессионально-миграционного поведения учебных мигрантов выглядит так: выраженная ориентация на проживание за рубежом с возможностью профессиональной деятельности в России - временная работа по трудовому контракту или же краткие профессиональные визиты. Особенно высока доля лиц, предпочитающих именно такую стратегию, среди студентов, обучающихся в США, и среди студентов, обучающихся по естественно-техническим специальностям. Вместе с тем, если рассматривать возвращение и эмиграцию не как чисто территориальное перемещение людей, а как циркуляцию интеллектуальных ресурсов, то существует значительный потенциал «интеллектуального возвращения» в Россию - в виде идей, профессиональных знаний и компетенций высококвалифицированных специалистов, которые, не желая возвращаться навсегда, тем не менее, не исключают для себя в будущем профессиональное сотрудничество с родиной в какой-либо форме. В современных концепциях глобализации интеллектуальных ресурсов «циркуляция идей» имеет не меньшее значение для развития интеллектуального и научно-технического потенциала страны-донора России, чем возврат людей.

Совершенно очевидно, что для многих молодых людей, в первую очередь наиболее одаренных и мотивированных, существует реальная возможность «закрепиться» на Западе, то есть найти работу либо в научных организациях, университетах, либо в частном бизнесе, международных структурах, транснациональных корпорациях и т.п. К тому же современная экономическая ситуация в России мало способствует «возвращенческим» настроениям. Неясны перспективы профессиональной деятельности в России, в частности, возможности трудоустройства по специальности, полученной на Западе, слаба информационная связь с коллегами на родине.

Создание определенных условий - профессиональных и финансово-материальных для возвращения молодых специалистов в Россию опирается на анализ факторов «возвратной миграции» или «компенсируемой миграции». Наиболее важный фактор в глазах это - материальный, т.е. высокая заработная плата. Следующий по значимости фактор - наличие высококлассной профессиональной среды. В комплекс факторов, необходимых для возврата, также входят возможность быстрого профессионального роста, возможность международных профессиональных контактов, зарубежных поездок, долгосроч- ная и стабильная занятость, трудоустройство в определенном городе России, доступ к современным информационным и коммуникационным технологиям.

Для принятия мер по стимулированию процесса обучения за рубежом и в то же время для возврата молодежи для дальнейшей работы в России Министерство образования и Агентство стратегических инициатив (АСИ) объявили о запуске государственной программы в начале 2014 г. Реализацией программы и приемом документов занимается бизнес-школа «Сколково». Эта программа рассчитана на выпускников российских вузов, которые хотят учиться за рубежом в магистратуре, докторантуре или ординатуре. Они независимо от того, какая у них специальность значится в дипломе, смогут повысить свою квалификацию по пяти специальностям: «образование» (менеджмент вуза, педагогика), «медицина», «инженерия», «наука», «социальная сфера» (специалист по экономике труда или госуправлению, менеджер в сфере культуры). Студенты имеют возможность получить грант на сумму 1,38 млн руб. на обучение в одном из 227 вузов 27 стран. После получения диплома выпускник должен вернуться на родину и в течение 3-6 месяцев устроиться работать в российскую компанию из утвержденного списка. Требования по отработке жесткие - три года. Те, кто не сделает этого, будут вынуждены заплатить штраф в два раза больше, чем сумма гранта. За год действия программы, несмотря на привлекательные условия для студентов, образовался недобор заявок. Претендовать на такой грант можно лишь будучи уже зачисленным в иностранный вуз. Большинство университетов, которые учитываются программой, находятся в США, Канаде, Великобритании, Германии и Австралии. «В случае нарушения условий программы участник обязан возвратить сумму предоставленного ему гранта, а также уплатить штраф в двукратном размере от суммы гранта. По состоянию на январь 2018 года, в программе участвуют 626 граждан, из которых 64 человека, отучившись за границей, вернулись домой и трудоустроились. (Романова, 2015).

Российские исследователи, изучающие проблемы образовательной миграции (Л. Леденева, Д. Митин, Е. Цапенко, О.В. Санникова и др. 71 (Митин, 2010, Санникова, 2015:203-206), отмечают, что наиболее перспективными направлениями деятельности по оказанию помощи молодым специалистам в начале профессиональной деятельности в России будут меры консульта- 
ционного и организационно-финансового характера, которые можно предложить в рамках специальной инициативы, направленной на возвращение интеллектуальных ресурсов в Россию. К ним можно отнести:

1) возможность проведения краткосрочного (1-2 года) исследовательского проекта в России и помощь в заключении долгосрочного трудового контракта в России;

2) квалифицированные консультации по рынку профессионального труда в России ввиду плохого знания молодыми специалистами, заканчивающими обучение за рубежом, российского рынка труда;

3) выработка целенаправленных программ индивидуальной работы с российскими студентами, заканчивающими обучение за границей по различным специальностям.

Базой для реализации всех трех указанных направлений деятельности должно служить создание банка данных, в том числе банка электронных адресов студентов-россиян, обучающихся в зарубежных университетах. В реализации этих задач необходимо объединение усилий всех заинтересованных государственных структур, научных и образовательных учреждений, бизнес-сообщества и социальных партнеров по выработке согласованной стратегии возвращения интеллектуальных ресурсов в Россию.

Таким образом, изучение российского опыта демонстрирует, что такая тенденции в образовательной миграции, как отток талантливой молодежи, является актуальным вопросом. В правительственных кругах предпринимаются меры по удержанию лучших специалистов в своей стране после окончания зарубежных вузов через финансовые и профессиональные стимулы. Вместе с тем, Россия сама стремится к расширению российских образовательных услуг и созданию условий для активизации учебной миграции в Россию путем оптимизации современной госу- дарственной миграционной политики, поскольку данный вид международной мобильности является эффективным ресурсом для укрепления позиций РФ на международной арене, развития ее экономики, оздоровления демографической ситуации, укрепления межкультурного диалога.

\section{Заключение}

Образовательную миграцию можно определить как перемещение с целью получения образования и/или осуществления трудовой деятельности в области образования, т. е. преподавания, проведения исследований. Образовательная миграция непосредственно связана с глобализацией, что является естественным сценарием развития всех стран. Особенностью российской образовательной миграции является осознанный и целенаправленный отток ученых, специалистов, профессионалов в европейские страны и США, так называемая «утечка мозгов». На образовательную миграцию (как внешнюю, так внутреннюю) повлиял экономический кризис последних лет, в условиях дефицита госбюджета было секвестрировано финансирование социальной сферы, в том числе образования, что явилось причиной падения качества образования, утраты профессионалов в высшей школе, «старения кадров», отставания материально-технической базы учебных заведений России от вузов ведущих стран.

Всестороннее изучение и анализ всех аспектов образовательной (учебной) миграции является важной задачей, поскольку это дает возможность моделировать и прогнозировать последствия миграции студентов, академической и профессиональной мобильности, планировать вопросы образовательно-культурного, научного и в целом гуманитарного сотрудничества между странами и повышения его эффективности.

\section{Литература}

Beech S. International Student Mobility: A Critical Overview // Laboring and Learning. - 2017. - P. 285-303.

Bijwaard G. E., Wang Q. Return migration of foreign students // European Journal of Population. - 2016. - T. 32. - №. 1. - P. 31-54.

Выхованец О. Д. Образовательная миграция как часть миграционной политики России //Федеральная миграционная служба России. URL:// http://www.fms.gov.ru /about/ science/science_session.

Волох В. А., Гришаева С. А. Международная образовательная миграция в современной России: особенности, проблемы и перспективы // Социальная политика и социология. - 2017. - Т. 16. - №. 1. - С. 80-87.

Goodhart D. The road to somewhere: the populist revolt and the future of politics. - Oxford University Press, 2017. $-256 \mathrm{p}$.

Goździak E. M. To dream or not to dream: The effects of immigration status, discrimination, and parental influence on Latino children's access to education // Migration Studies. - 2014. - T. 2. - №. 3. - P. 392-414.

Громова Е. А., Бояркин Г. Н. Проблемы и перспективы развития образовательной (учебной) миграции в современной России // Креативная экономика. - 2011. - №. 7.- С.105-113. 
Демографические вызовы России. Экспертно-аналитический доклад // Центр стратегических разработок «Человеческий капитал». - 2017.// https://www.csr.ru/wp-content/uploads/2017/11/Report-Demography-web.pdf.

Dustmann C., Fadlon I., Weiss Y. Return migration, human capital accumulation and the brain drain //Journal of Development Economics. - 2011. - T. 95. - №. 1. - P. 58-67.

Education at Glance 2018. 2003.

Забирова А. Теории и концепции процессов миграции в зарубежной социальной науке // Евразийское сообщество, №2,

«Концепция государственной миграционной политики Российской Федерации на период до 2025 года» // https://www. consultant.ru/document/cons_doc_LAW_131046/Choudaha R. Three waves of international student mobility (1999-2020)// Studies in Higher Education. - 2017. - T. 42. - №. 5. - P. 825-832.

Collins F.L. Researching mobility and emplacement: Examining transience and transnationality in international student lives // Area. - 2012. -№44 (3).- P. 296-304.

Леденева Л. Студенты-россияне, обучающиеся на Западе: перспективы возвращения в Россию // Migracijske i etničke teme. - 2002. - № 18. - С. 177-196.

Леденева В.Ю. Интеллектуальная миграция: мировые и российские тенденции // Высшее образование в России - 2014. - №2. - С. 35-42 // Новое молодежное движение: учиться - на западе, работать - тоже. // http: //sd .and. ru/ letters/immigration_news-89.html

Lulle A., Buzinska L. Between a 'student abroad' and 'being from Latvia': inequalities of access, prestige, and foreign-earned cultural capital // Journal of Ethnic and Migration Studies. - 2017. - T. 43. - №. 8. - P. 1362-1378.

Madge, C., Raghuram P., Noxolo P. Engaged pedagogy and responsibility: A postcolonial analysis of international students // Geoforum. - 2009. - №40 (1) - P. 34-45.

Масич В.А. Наука и образование как инструменты «мягкой силы» // Практики исследования общественно-политических процессов. - 2015. - С. 117-125

Митин Д.Н. Образовательная (учебная) миграция: понятие, проблемы и пути решения//Вестник РУДН, серия Политология. - 2010. - № 3; Санникова О.В. Некомпенсируемая образовательная миграция: социальные последствия и индивидуальные основания // Научные исследования: от теории к практике : материалы VI Междунар. науч.-практ. конф. - 2015. / редкол.: О.Н. Широков [и др.] - Чебоксары: ЦНС «Интерактив плюс». - 2015. - С. 203-206; О.Цапенко. Международная студенческая миграция. //http://www.cyberleninka.ru/article/n/ mezhdunarodnaya-studencheskaya - migratsiya.

Молодежь России на рубеже XX-XXI веков: образование, труд, социальное самочувствие [Текст] : монография / Д.Л. Константиновский, Е.Д. Вознесенская, Г.А. Чередниченко. - М.: ЦСПиМ, 2014. - 548 с

Nishimuta, Y. The interpretation of racial encounters: Japanese students in Britain // Journal of Ethnic and Migration Studies. 2008. -№34 (1). - P. 133-150.

Новиков В. С. Образовательная услуга как составной социально-экономический конструкт глобализации // Сборники конференций НИЦ, 2011. - №. 30.-С.17-30.

Salt J. International Movements of the Highly Skilled//OESD Social, Employment and Migration Working Papers, N 3.- 1997

Письменная Е. Е., Рязанцев С. В., Скоробогатова В. И. Иностранные образовательные мигранты в России и их доступ на рынок труда // Миграционные мосты в Евразии. - 2015. - С. 156-163.

Путин В.В. Надо обратить внимание на работу иностранных НКО в школах. РИА новости - информационное агентство РФ. // https://ria.ru/society/20150624/1084949791.html

Tan, J. Introduction // The International Mobility of Students in Asia and the Pacific. Paris: UNESCO. - 2013. - P. 1-5.

Романова С. Госпрограмма обучения студентов за рубежом буксует // Ведомости. - 2015.

Самофалова Е.И. Особенности изучения образовательной миграции в трудах зарубежных авторов// Вестник ТГУ, 2015 , №1(29), c. 105-110.

Simon Nimako. Construct specification and misspecification within the application of push-pull mooring theory of switching behavior//Journal of Business and Management Sciences/Volume 1,issue5. Pp 83-95

Трофимов Е.А., Трофимова Т.И. Особенности учебной миграции в условиях глобализации // Тенденции и проблемы в экономике России: теоретические и практические аспекты. Всерос. науч.-практ. конф. / под ред. С.А. Курганского. Иркутск: Изд-во БГУ. - 2017. - 293 c. // http://www.aif.ru/boostbook/obrazovanie-v-rossii-i-za-rubezhom.html.

Wu C., Wilkes R. International students' post-graduation migration plans and the search for home // Geoforum. - 2017. - T. 80. - P. 123-132.

Yue, C. International Student Mobility: China.// The International Mobility of Students in Asia and the Pacific. Paris: UNESCO. - 2013. - P. 18-28.

Фоминых А. Е. Российские университеты на образовательных рынках Центральной Азии: публичная дипломатия, сотрудничество и конкуренция //Вестник Томского государственного университета. История. - 2014. - №. 6 (32).- С. 28-31.

\section{References}

Beech S. International Student Mobility: A Critical Overview // Laboring and Learning. - 2017. - P. 285-303.

Bijwaard G. E., Wang Q. Return migration of foreign students // European Journal of Population. - 2016. - T. 32. - №. 1. P. 31-54.

Vykhovanets O. D. Obrazovatelnaya migratsia kak chast migratsionnoy politiki Rossii //Federalnaya migratsionnaya sluzhba Rossii URL:// http://www.fms.gov.ru /about/ science/science_session. 
Volokh V. A., Grishaeva S. C. A. Mezhdunarodnaya obrazovatelnaya migratsia v sovremennoy Rossii: osobennosti, problem I perspectivy // Socialnaya politika i sotsiologiya. - 2017. - T. 16. - №. 1. - C. 80-87.

Goodhart D. The road to somewhere: the populist revolt and the future of politics. - Oxford University Press, 2017. - 256 p.

Goździak E. M. To dream or not to dream: The effects of immigration status, discrimination, and parental influence on Latino children's access to education // Migration Studies. - 2014. - T. 2. - №. 3. - P. 392-414.

Gromova E. A., Boyarkin G.N. Problemy i perspectivy razvitiya obrazovatelnoy( uchebnoy) migratsii v sovremennoy Rossii // Kreativnaya economika- 2011. - №. 7.- C.105-113.

Demographicheskie vyzovy Rossii. Expertno-analiticheskiy doklad // Tsenter strategicheskikh razrabotok «Chelovecheskiy capital ». - 2017. // https://www.csr.ru/wp-content/uploads/2017/11/Report-Demography-web.pdf.

Dustmann C., Fadlon I., Weiss Y. Return migration, human capital accumulation and the brain drain //Journal of Development Economics. - 2011. - T. 95. - №. 1. - P. 58-67.

Education at Glance 2018

Zabirova A. Teorii I kontseptsii protsessov migratsii v zarubezhnoy sotsialnoy nauke науке // Evraziyskoe soobchestvo, №2, 2003

«Kontsepsia gosudarstvennoy migratsionnoy politiki Rossiyskoy federatsii na period do 2025 »// https://www.consultant.ru/ document/ cons doc LAW 131046/

Choudaha R. Three waves of international student mobility (1999-2020) // Studies in Higher Education. - 2017. - T. 42. - № 5. - P. 825-832.

Collins F.L. Researching mobility and emplacement: Examining transience and transnationality in international student lives // Area. - 2012. -№44 (3).- P. 296-304.

Ledeneva L. Studenty-rossiyane, obuchauchiesya na Zapade; perspectivy vozracheniya v Rossiuв // Migracijske i etničke teme. -2002 . - № 18. - C. 177-196.

Ledeneva L.. Intellectualnaya migratsia; mirovye I rossiyskie // Vyshee obrazovanie d Rossii la- 2014. - №2. -C.35-42 //Novoe molodezhnoe dvizhenie;uchitsya na zapade, rabotat -tozhe // http: //sd .and. ru/ letters/immigration_news-89.html

Lulle A., Buzinska L. Between a 'student abroad' and 'being from Latvia': inequalities of access, prestige, and foreign-earned cultural capital // Journal of Ethnic and Migration Studies. - 2017. - T. 43. - №. 8. - P. 1362-1378.

Madge, C., Raghuram P., Noxolo P. Engaged pedagogy and responsibility: A postcolonial analysis of international students // Geoforum. - 2009. - №40(1) - P. 34-45.

Masich V.A. Nauka Iobrazovaniekaka instrumenty «myagkoy sily»//Praktiki issledovaniya obschestvennj-politicheskikh.-2015.C.117-125

Mitin D.N. Obrazovatelnaya (uchebnaya) migratsia; ponyatie, problem I puti resheniya //Vestnik RUDN, seriya Politologiya.2010. - № 3; Sannikova O.V. Nekompensiruemaya obrazovatelnaya migratsia: socialnye posledstviya b industrialnye osnovaniyua // Nauchnye issledovaniya: ot teorii k praktike/ redkollegiya: O.N. Shirokov- Cheboksary: CNS «Interaktiv plus ». - 2015. - C. 203-206; O. Tsapenko. Mezhdunarodnaya studencheskaya migratsiya. // http://www.cyberleninka.ru/article/n/ mezhdunarodnayastudencheskaya-migratsiya.

Molodezh Rossii na rubezhe XX-XXI vekov: obrazovanie, trud, socialnoe samochuvstvie: monographiya / D.L. Konstantinovskiy, E.D. Voznesenskaya, G.A. Cherednichenko. - M.:, 2014.

Nishimuta, Y. The interpretation of racial encounters: Japanese students in Britain // Journal of Ethnic and Migration Studies. - 2008. -№34 (1). - P. 133-150.

Novikov V. S. Obrazovatelnaya usluga kak sostavnoy sotsialno-economicheskiy konstrukt globalizatsii // Sborniki konferentsiy NITs, 2011. - №. 30.-C.17-30.

Salt J. International Movements of the Highly Skilled//OESD Social, Employment and Migration Working Papers, No 3,1997

Pismennaya E. E., Ryazantsev S.V. Skorobogatov V.I. Inostrannye obrazovatelnye migrant v Rossii I ikh dustup na rynok truda // Migratsionnye mosty v Evrazii. - 2015. - C. 156-163.

Putin V.V. Nado obratit vnimanie na raboty zarubezhnykh NKO v shkolakh. PIA novosti - informatsionnoe agenstvo RF // https://ria.ru/society/20150624/1084949791.html

Tan, J. Introduction // The International Mobility of Students in Asia and the Pacific. Paris: UNESCO. - 2013. - P.1-5.

Romanova S. Gosprogramma obucheniya studentov za rubezhom buksuet // Vedomosty. - 2015.

Samofalova E.I. Ossobennosti izucheniya obrazovatelnoy migratsii v trudakh zarubezhnykh avtorov // Vestnik TGU, 2015, №1(29), c. 105-110.

Simon Nimako. Construct specification and misspecification within the application of push-pull mooring theory of switching behavior//Journal of Business and Management Sciences/Volume 1,issue5. Pp 83-95

Trofimov e.A., Trofimova T.I. Osobennosti uchebnoy migratsii v usloviyakh globallizatsii // Tendentsii I problem v economike Rossii: teoreticheskie I prakticheskie aspecty / pod red. S.A. Kurganskogo. - Irkutsk: Izdatelstvo BGU. - 2017. - 293 c. // http:// www.aif.ru/boostbook/obrazovanie-v-rossii-i-za-rubezhom.html.

Wu C., Wilkes R. International students' post-graduation migration plans and the search for home // Geoforum. - 2017. - T. 80. - P. 123-132.

Yue, C. International Student Mobility: China.// The International Mobility of Students in Asia and the Pacific. Paris: UNESCO. -2013. - P. 18-28.

Fominykh A. E. Rossiyskie universitet na obrazovatelnykh rynkakh Centralnoy Asii: publichnaya diplomatiay, sotrudnichestvo I konkurentsiya // Vestnil Tomskogo gosudarstvennogo universiteta. Istoriya- 2014. - №. 6 (32).- C. 28-31. 